\title{
ENHANCING INTERETHNIC TOLERANCE IN MASTERS OF EDUCATION IN UKRAINIAN MULTIETHNIC PRIMARY SCHOOL
}

\author{
AUMENTANDO A TOLERÂNCIA INTERÉTNICA EM MESTRES DA EDUCAÇÃO NA \\ ESCOLA PRIMÁRIA MULTIÉTNICA DA UCRÂNIA
}

\section{MEJORA DE LA TOLERANCIA INTERÉTNICA EN MÁSTER DE EDUCACIÓN EN LA ESCUELA PRIMARIA MULTIÉTNICA DE UCRANIA}

\author{
Olena Bartosh ${ }^{1}$ 0000-0001-6733-5516 \\ Tetiana Atroshchenko² 0000-0003-4595-1662 \\ Iryna Kozubovska ${ }^{3}$ 0000-0002-5562-0472
}

${ }^{1}$ State University Uzhhorod National University, Ucrânia; olena.bartosh@uzhnu.edu.ua
${ }^{2}$ Mukachevo State University, Ucrânia; tatiyana41@i.ua
${ }^{3}$ State University Uzhhorod National University, Ucrânia; kozub@hotmail.com

\section{RESUMO:}

A tolerância interétnica é uma parte determinante da competência profissional do Mestrado em Educação (Ensino Primário) na Ucrânia. É vista tanto como uma ordem social para o sistema educacional moderno, como uma qualidade pessoal-profissional formada com base na cosmovisão humanística, permitindo o desempenho das funções profissionais de forma eficaz. O objetivo do artigo é introduzir a educação de Mestres em Educação no contexto da formação da tolerância interétnica para desempenhar funções profissionais no ambiente educacional multiétnico da escola primária. O artigo examina a experiência de 199 Mestres em Educação (Ensino Fundamental) que se formaram com a estratégia de aprendizagem para melhorar o nível de tolerância interétnica formada. Usamos uma combinação de métodos de pesquisa: análise de documentos normativos e currículos, observação do desempenho dos alunos, questionário, teste, experimento pedagógico, análise quantitativa e qualitativa de dados experimentais. Para melhorar o nível de tolerância interétnica formado, desenvolvemos e introduzimos um suporte metódico para a organização eficaz do extra / currículo, do trabalho independente e da prática pedagógica. O procedimento de aprendizagem desenvolvido, implementado no grupo experimental, deu resultados positivos na formação da tolerância interétnica pelos componentes valor motivacional, cognitivo, atividade-comportamental e reflexivo-criativo. $\mathrm{O}$ número de alunos do grupo experimental com alto nível de tolerância interétnica formado aumentou 23,48\%; com nível suficiente - aumentou 14,54\%; com nível médio e nível baixo - diminuíram $16,07 \%$ e $21,94 \%$, respectivamente. Os resultados da pesquisa são relevantes para outros programas educacionais.

Palavras chave: ambiente educacional multiétnico da escola primária; currículo; mestres em educação.

\begin{abstract}
:
Interethnic tolerance is a determining part of professional competence of Masters of Education (Primary Teaching) in Ukraine. It is seen both as a social order for the modern education system, as a personal-professional quality formed on the basis of humanistic worldview, allowing to perform professional duties effectively. The paper's aim is to introduce education of Masters of Education into the context of interethnic tolerance formation to perform professional duties in the multiethnic educational environment of primary school. The paper examines the
\end{abstract}


experience of 199 Masters of Education (Primary Teaching) who graduated with the learning strategy to improve the level of interethnic tolerance formed. We used a combination of research methods: analysis of normative documents and curricula, observation of students' performance, questionnaire, testing, pedagogical experiment, quantitative and qualitative analysis of experimental data. To improve the level of interethnic tolerance formed we developed and introduced methodical support for the effective organisation of extra/curriculum, independent work and pedagogical practice. The developed learning procedure, implemented in the experimental group, gave positive results in the formation of interethnic tolerance by motivational-value, cognitive, activity-behavioural, and reflexivecreative components. The number of students in the experimental group with high level of interethnic tolerance formed increased by $23.48 \%$; with sufficient level - increased by $14.54 \%$; with average and low level - decreased by $16.07 \%$ and $21.94 \%$, respectively. The research findings are relevant for other educational programs.

Keywords: curriculum; masters of education; multiethnic educational environment of primary school.

\section{RESUMEN:}

La tolerancia interétnica es una parte determinante de la competencia profesional de los Maestros en Educación (Enseñanza Primaria) en Ucrania. Se ve tanto como un orden social para el sistema educativo moderno, como una cualidad personal-profesional formada sobre la base de la cosmovisión humanista, que permite desempeñar eficazmente los deberes profesionales. El objetivo del documento es introducir la educación de los Maestros en Educación en el contexto de la formación de tolerancia interétnica para desempeñar deberes profesionales en el entorno educativo multiétnico de la escuela primaria. El artículo examina la experiencia de 199 Maestros en Educación (Enseñanza Primaria) que se graduaron con la estrategia de aprendizaje para mejorar el nivel de tolerancia interétnica formado. Utilizamos una combinación de métodos de investigación: análisis de documentos normativos y planes de estudio, observación del desempeño de los estudiantes, cuestionario, pruebas, experimento pedagógico, análisis cuantitativo y cualitativo de datos experimentales. Para mejorar el nivel de tolerancia interétnico formado, desarrollamos e introdujimos un apoyo metódico para la organización efectiva de actividades extracurriculares, trabajo independiente y práctica pedagógica. El procedimiento de aprendizaje desarrollado, implementado en el grupo experimental, arrojó resultados positivos en la formación de tolerancia interétnica por componentes de valor motivacional, cognitivo, actividad-comportamiento y reflexivo-creativo. El número de alumnos del grupo experimental con alto nivel de tolerancia interétnica formado aumentó en un 23,48\%; con nivel suficiente - aumentado en un $14,54 \%$; con nivel medio y bajo - disminuyó un 16,07\% y un 21,94\%, respectivamente. Los resultados de la investigación son relevantes para otros programas educativos.

Palabras clave: entorno educativo multiétnico de la escuela primaria; maestría en educación; plan de estudios.

\section{Introduction}

The society need for teachers, able to take a humane, personality-oriented position in relation to both pupils and themselves, puts forward topical issues of teacher professional competence. Tihomirova (2011) states, that the ongoing global processes, having qualitatively changed children's generations, their intellectual, psychological, and moral components of 
consciousness and behavior, have conditioned the task of ensuring the transition to a new paradigm of education and upbringing.

Globalisation processes impact education systems, requiring a new generation of primary school teachers trained to perform professional duties by the requirements of multicultural education. In Ukraine, the development and implementation of educational programs, that promote humanization of interethnic relations and address the issue of overcoming tension between educational process participants, is seen as a social order for the modern education system (Dovhopolova, 2007; Kapidinova, 2015; Kondratieva, 2016; Pashchenko, 2006). Thus, Ukrainian universities face the task to train primary school teachers ready to direct the educational process on the formation of tolerant schoolchildren, capable to understand and appreciate the uniqueness of national and other cultures (Khoma, 2013; Slyusarenko and Kadaner, 2017).

The paper aims to introduce education of Masters of Education (Primary Teaching) (MEdPT) into the context of interethnic tolerance (IT) formation to perform professional duties in the multiethnic educational environment of primary school (MEEPS). The study rationale rests on assumption that there is: (i) an objective need to organize professional training of MEdPT who demonstrate high level of IT in the MEEPS; (ii) an unused potential of educational courses and pedagogical practice directed on IT formation.

\section{Método Caracterização da amostra}

A amostra utilizada na presente investigação foi selecionada por método não probabilístico de conveniência (Hill \& Hill, 2005; Maroco, 2007), sendo constituída por 27 sujeitos- 16 do género feminino e 11 do género masculino - com 9 anos de idade e com frequência no $4 .^{\circ}$ ano de escolaridade. Os sujeitos da amostra possuem como língua materna o português, e não apresentam diagnóstico de dificuldades na leitura e escrita, segundo os relatórios elaborados pela psicóloga do Serviço de Psicologia e Orientação.

A recolha de dados foi realizada numa instituição privada do centro do país, em região urbana, com a devida autorização da instituição e dos encarregados de educação dos participantes.

\section{Materials and Methods}


The survey sample was made up of 199 MedPT who graduated in 2018/19 - 2019/20 academic years from Ukrainian universities with the learning strategy to improve IT level.

We carried out the research in stages: 1) clarified the structure of IT of MEdPT by components, indicators of components, and levels (June - August 2017); 2) conducted the pilot study of curricula of Ukrainian universities aimed at IT formation in MEdPT (September December 2017); 3) developed the course "Theory and practice of IT of primary school teachers" and the program of pedagogical experiment (January - August 2018); 4) selected control group (CG) and experimental group (EG); carried out the pedagogical experiment; defined the levels of IT formed in the CG and EG before and after the experiment, and processed the data obtained (September 2018 - December 2019).

We used a combination of research methods to answer the research task: analysis of normative documents and curricula, observation of students' performance, questionnaire, testing, pedagogical experiment, quantitative and qualitative analysis of experimental data.

\section{Results}

\section{The structure of IT}

Determining the IT essence involved further study of its structure, namely components, which we believed were the most important and significant elements. They reflected fully and holistically the peculiarities of IT formation in MedPT and helped to assess the effectiveness of the implemented learning procedure.

Generalization of views of Gryva (2007) and Tyshchyk (2013) on IT componentstructural composition allowed determining the motivational-value, cognitive, activitybehavioral, and reflexive-creative components. These met the criteria of content adequacy and formation specificity; clear reflection of learning outcomes and compliance with didactic goals; approachability and easement in application; feasibility to check based on quantitative and qualitative analysis. In the Table 1 we specified the components by indicators, adequate to qualitatively and quantitatively diagnose the levels of IT formed.

\section{Table 1. IT components: characteristics and indicators}

\begin{tabular}{lllr}
\hline \multicolumn{1}{c}{ Component } & \multicolumn{1}{c}{ Characteristics } & \multicolumn{2}{c}{ Indicators } \\
\hline Motivational- & Is based on the awareness of IT role and importance & Motivation to \\
value & as a precondition for the successful professional & improve IT. Stability \\
& activity in the MEEPS. Is characterized by: displays & of interest in the \\
& of pronounced interest in IT; lack of stereotypes and & study of ethnic \\
prejudice towards ethnic groups; conscious belief & groups & culture. \\
& that people should be evaluated by personal qualities & Focus on universal \\
and not by ethnicity. & human values.
\end{tabular}


Cognitive Includes knowledge on: native and ethnic cultures (moral and ethical values, traditions, and customs); norms and rules of interethnic relations; human rights and freedoms; essence of IT, methods and techniques of its formation; introduction of children into the world of customs and traditions of various peoples.

Activity- Involves skills: organisational-communicative behavioural (based on etiquette, tolerance, and respect for cultural characteristics); control-evaluative (control over behaviour and emotions in the communication process, adequate assessment of opponents' reaction); and intellectual-prognostic (comparison of goals set with the results obtained, prognostication of actions and consequences).

Reflexive- Is characterized by reflection and adequate creative assessment of IT. It provides awareness of how can one evaluate the attitude to ethnic groups and on this basis organize practical activities in the MEEPS. It testifies to the level of reflection on the formation of personal qualities necessary for the interaction with ethnic groups in the MEEPS.

Thorough knowledge on IT. Multicultural competence. Social active position in defending the rights and freedoms of ethnic groups.

Attitude to ethnic groups. Positive ethnic identity. No negative ethnic stereotypes.

Ability to reflect. Displays of sociability and friendliness, desire for cooperation. Formed empathy.

Based on findings of Bartosh (2020) and Tyshyk (2013), we were in favor of four-level approach to the defining of IT formed in MedPT, as demonstrated in the Table 2.

Table 2. Levels of IT formed in MEdPT

\section{Level Characteristics}

Low Fragmentary knowledge on IT, native culture; ignorance of norms and rules of interethnic communication in the MEEPS; weak focus on universal values and interest in studying of ethnic groups culture; lack of empathy, strong negative assessment and snub attitude towards ethnic groups; negative ethnic stereotypes prevail; ethno egoism is demonstrated in situations of interethnic contact with displays of hostility, rudeness, aggression, and social passivity.

Average Mediocre knowledge on IT, native and ethnic groups culture; situation followed norms and rules of interethnic communication; weak desire to self-interest in studying of ethnic groups; inactivity in IT formation in the course of extra/curricular activities; displays of ethnic indifference, sociability, friendliness in situations of interethnic contacts in the MEEPS; initiative sporadic 
displays; general assimilation of IT norms, incomplete comprehension of individual characteristics of ethnic groups, nation, culture, religion.

Sufficient Thorough knowledge on IT, native and ethnic groups culture, but its fragmentarity at practice; formed human dignity, focus on improvement of selfimage perception and image of ethnic groups representatives; adherence to norms and rules of interethnic communication; interest in studying of ethnic culture issues; sensitivity to ethnic problems of MEEPS participants; developed control over behavior in interethnic conflicts; almost no negative ethnic stereotypes; adequate social distance; proper level of communication skills; search for effective cooperation with MEEPS participants.

High In-depth knowledge on IT; developed belief that people should be addressed by personal qualities, not by ethnicity; no negative stereotypes and prejudice towards MEEPS participants; clear understanding that all ethnic groups have the right to speak their language, adhere to their traditions and customs, profess their religion; compliance with norms and rules of interethnic communication; high level of empathy for a communication partner; minimal importance of social distance; high sociability level; will and ability to resolutely stop intolerant actions; developed skills to engage in constructive dialogue with MEEPS participants.

\section{Improvement and provision of the learning procedure}

In the methodological context, during the pilot study we analyzed the curricula delivered to MEdPT in Ukrainian universities. We found out that universities did not provide any special course directly aimed to form IT and prepare MEdPT for the MEEPS. Particular courses (Didactics, organisation and management in primary school; Modern pedagogical technologies in primary school; Professional-personal development of a primary school teacher; Socialpedagogical work in educational institutions) covered only general issues of methodology for intercultural communication of MEdPT in the MEEPS.

Thus, we developed and taught EG the special course "Theory and practice of IT of primary school teachers" ( 3 credits) to improve understanding of IT concepts, technologies of IT diagnostics and formation, assessment of pedagogical situation in the MEEPS. Table 3 demonstrates the course descriptor.

Table 3. Descriptor of the course "Theory and practice of IT of primary school teachers"

\begin{tabular}{|c|c|}
\hline Theme & Issues covered \\
\hline $\begin{array}{l}\text { 1. Preconditions for the } \\
\text { development } \\
\text { multicultural education }\end{array}$ & $\begin{array}{l}\text { Origin and development of multicultural education. Moder } \\
\text { world ethnic picture. Cultural, linguistic and spiritual diversi } \\
\text { of society. }\end{array}$ \\
\hline
\end{tabular}




\begin{tabular}{|c|c|}
\hline $\begin{array}{l}\text { 2. Multicultural education } \\
\text { as a factor of formation of } \\
\text { tolerant interethnic } \\
\text { relations }\end{array}$ & $\begin{array}{l}\text { Cultural interaction in the context of multicultural educational } \\
\text { environment. Cultural pluralism. Cultural distance and } \\
\text { intercultural conflicts. Migration, tourism and social-economic } \\
\text { cooperation as factors of multiculturalism. Development of } \\
\text { interethnic communication culture. }\end{array}$ \\
\hline $\begin{array}{l}\text { 3. Ethno-pedagogical } \\
\text { competence in multicultural } \\
\text { education }\end{array}$ & $\begin{array}{l}\text { Priority tasks of multicultural education: personal } \\
\text { development, formation of ethno-cultural competence, } \\
\text { awareness of mutual influence and enrichment of cultures. } \\
\text { Structure of teacher's multicultural competence. Pedagogical } \\
\text { technologies in the multicultural education. }\end{array}$ \\
\hline $\begin{array}{l}\text { 4. The concept of } \\
\text { "tolerance" and "IT" }\end{array}$ & $\begin{array}{l}\text { Tolerance role in the overall "world picture" of an individual. } \\
\text { Individuality. Equality. Extremism and terrorism in the context } \\
\text { of interethnic and intercultural relations. Individual-directed } \\
\text { pedagogy in providing conditions for IT formation. }\end{array}$ \\
\hline $\begin{array}{l}\text { 5. Scientific-theoretical } \\
\text { basis of IT formation of } \\
\text { primary school teachers }\end{array}$ & $\begin{array}{l}\text { Multicultural competence as a precondition for effective } \\
\text { professionalism. IT as a component of professionalism. The } \\
\text { role of multicultural environment of universities. }\end{array}$ \\
\hline $\begin{array}{l}\text { 6. IT formation of primary } \\
\text { school teachers }\end{array}$ & $\begin{array}{l}\text { Content of pedagogical practice in a multiethnic region. The } \\
\text { role of extracurricular professionally directed work. }\end{array}$ \\
\hline $\begin{array}{l}\text { 7. Training of primary } \\
\text { school teachers to develop } \\
\text { IT and culture of interethnic } \\
\text { communication }\end{array}$ & $\begin{array}{l}\text { Theoretical aspects of IT formation in primary schoolchildren. } \\
\text { Ways and means of training to form IT and culture of } \\
\text { interethnic communication in primary schoolchildren during } \\
\text { extra / curricular activities. }\end{array}$ \\
\hline $\begin{array}{l}\text { 8. Interaction of primary } \\
\text { school teachers with } \\
\text { parents in the MEEPS }\end{array}$ & $\begin{array}{l}\text { Specificity of: family and school interaction; teacher activity } \\
\text { aimed to improve pedagogical culture of parents. }\end{array}$ \\
\hline
\end{tabular}

To improve IT formation in MEdPT we used the following teaching methods:

Case method. It contributed to the in-depth knowledge on interethnic communication norms and understanding of importance of universal values in the context of knowledge on value orientations of ethnic groups. MEdPT mastered the skills to organize intercultural dialogue with ethnic groups and resolve conflict situations. Faced with a specific situation, MEdPT learned to discuss, draw sound conclusions, and develop recommendations for choosing the behavior strategy in the MEEPS. Table 4 demonstrates examples of cases.

Table 4. Indicative examples of cases

\begin{tabular}{ll}
\hline Case & \multicolumn{1}{c}{ Tasks } \\
\hline 1. & In the class, almost all pupils are against one boy, who belongs to the ... ethnic group. \\
& Provide arguments on teacher's strategy to solve the problem: act calmly, do not pay \\
attention to the conflict; be attentive to the pupil; convince schoolchildren of their \\
misbehavior; speak on the issue at parent meetings and ask parents to neutralize child \\
aggression; offer your option. \\
A class joined a pupil from countryside, who spoke a typical dialect. Children mock \\
and openly laugh at a pupil. Provide arguments on teacher's strategy to solve the \\
problem: behave friendly, be attentive to the pupil; entrust the pupil with a task a
\end{tabular}


pupil can successfully handle to level up authority among classmates; not to interfere in the relationship between children, as over time, they themselves set communication; give a pupil some practical advice on how to behave; ask the most authoritative pupil in the class to take a newcomer under care; offer your option.

Training. Based on findings of Fedorchuk (2003) and Smulson (2004), we worked out and taught social-pedagogical training "IT as a factor of professionalism of primary school teachers" (10 sessions, 80 minutes each). Table 5 discloses its contents.

Table 5. Training "IT as a factor in the professionalism of MEdPT"

\begin{tabular}{|c|c|c|c|}
\hline № & $\begin{array}{l}\text { Module } \\
\text { content }\end{array}$ & Aim - to: & Exercises \\
\hline \multirow[t]{7}{*}{1} & \multirow{13}{*}{$\begin{array}{l}\text { Get to know } \\
\text { oneself }\end{array}$} & \multirow{7}{*}{$\begin{array}{l}\text { Develop rules and } \\
\text { establish } \\
\text { relationships in a group }\end{array}$} & Introduction \\
\hline & & & Exercise: Hopes and expectation tree \\
\hline & & & Exercise: Personal acquaintance \\
\hline & & & Conversation: Rules of our group \\
\hline & & & Game: Stick \\
\hline & & & Game: The most... \\
\hline & & & Reflection on exercise: Rock \\
\hline \multirow[t]{6}{*}{2} & & \multirow{6}{*}{$\begin{array}{l}\text { Form interest in the } \\
\text { process of self- } \\
\text { cognition. Consolidate } \\
\text { and comprehend } \\
\text { personal ethnic features }\end{array}$} & Mini-lecture: Handshake or bow \\
\hline & & & $\begin{array}{l}\text { Group discussion: Functions of positive } \\
\text { MEEPS in the upbringing of primary } \\
\text { schoolchildren }\end{array}$ \\
\hline & & & Exercise: Unlike me \\
\hline & & & Game: Picture of an ethnic group \\
\hline & & & Exercise: Role play \\
\hline & & & $\begin{array}{l}\text { Presentation: Value orientations of ethnic } \\
\text { groups }\end{array}$ \\
\hline \multirow[t]{7}{*}{3} & \multirow{13}{*}{$\begin{array}{l}\text { Social } \\
\text { sensitivity } \\
\text { towards } \\
\text { communication } \\
\text { partner }\end{array}$} & \multirow{7}{*}{$\begin{array}{l}\text { Study the causes of } \\
\text { negative ethnic } \\
\text { stereotypes and features } \\
\text { of non-/ verbal } \\
\text { communication of } \\
\text { various ethnic groups }\end{array}$} & Exercise: Greetings \\
\hline & & & Blitz Poll: Our Names \\
\hline & & & Exercise: Make a chain \\
\hline & & & Game: Hello, salute, shalom \\
\hline & & & Game: Meeting \\
\hline & & & $\begin{array}{l}\text { Debates with pre-given position: Analysis } \\
\text { of proverbs }\end{array}$ \\
\hline & & & Exercise: Unconventional farewell \\
\hline \multirow[t]{6}{*}{4} & & \multirow{6}{*}{$\begin{array}{l}\text { Study ethnic diversity. } \\
\text { Control emotions. Form } \\
\text { skills to set positive } \\
\text { atmosphere }\end{array}$} & Exercise: Get to circle middle \\
\hline & & & Game: Acquaintance in an airport \\
\hline & & & Exercise: Say No to ethnic stereotypes \\
\hline & & & Exercise: Friendship Thread \\
\hline & & & Game: Justification or Denial \\
\hline & & & Reflection \\
\hline \multirow[t]{5}{*}{5} & \multirow{5}{*}{$\begin{array}{l}\text { An individual } \\
\text { among the } \\
\text { others }\end{array}$} & \multirow{5}{*}{$\begin{array}{l}\text { Overcome and prevent } \\
\text { prejudice in } \\
\text { communication. } \\
\text { Improve } \\
\text { communicative skills }\end{array}$} & Warm-up: Counting on condition \\
\hline & & & Exercise: Association \\
\hline & & & Exercise: Guess who we talk about \\
\hline & & & Exercise: Ambiguous images \\
\hline & & & Game: Labelling \\
\hline
\end{tabular}


Olena Bartosh • Tetiana Atroshchenko • Iryna Kozubovska

\begin{tabular}{|c|c|c|c|}
\hline \multirow{9}{*}{6} & & & Exercise: Nuts \\
\hline & & & Reflection \\
\hline & & \multirow{7}{*}{$\begin{array}{l}\text { Improve skills of } \\
\text { mutual understanding in } \\
\text { conditions of activation } \\
\text { of negative ethnic } \\
\text { stereotypes }\end{array}$} & Exercise: Greetings \\
\hline & & & Game: Island \\
\hline & & & Dispute: I believe \\
\hline & & & Exercise: Draw a problem \\
\hline & & & Mini-lecture: Cultural norms and values \\
\hline & & & Exercise: Communication with foreigners \\
\hline & & & Game: Complement \\
\hline \multirow[t]{7}{*}{7} & \multirow{13}{*}{$\begin{array}{l}\text { Me from } \\
\text { position of } \\
\text { ethnic groups }\end{array}$} & \multirow{7}{*}{$\begin{array}{l}\text { Deepen knowledge on } \\
\text { in / tolerant individual. } \\
\text { Develop confidence in } \\
\text { behavior. Develop } \\
\text { personal and } \\
\text { professional reflection }\end{array}$} & Exercise: Greetings \\
\hline & & & Game: Association bag \\
\hline & & & Presentation: What is "IT" \\
\hline & & & Game-situation: Cases in the MEEPS \\
\hline & & & Exercise: Foreigner \\
\hline & & & $\begin{array}{l}\text { Mini-lecture: Positive psychological } \\
\text { atmosphere in the MEEPS }\end{array}$ \\
\hline & & & Exercise: Rhythmic applause \\
\hline \multirow[t]{6}{*}{8} & & \multirow{6}{*}{$\begin{array}{l}\text { Develop skills to } \\
\text { present oneself from } \\
\text { various positions. Find a } \\
\text { productive way to } \\
\text { prevent and resolve } \\
\text { interethnic conflicts }\end{array}$} & Exercise: Meeting \\
\hline & & & $\begin{array}{l}\text { Mini-lecture: Features of interethnic } \\
\text { tolerant individual }\end{array}$ \\
\hline & & & Game: Emblem of IT \\
\hline & & & $\begin{array}{l}\text { Game: An individual with specific } \\
\text { features }\end{array}$ \\
\hline & & & Exercise: In / tolerant behavior \\
\hline & & & Reflection: I'd like to give you a gift \\
\hline \multirow[t]{7}{*}{9} & \multirow{14}{*}{$\begin{array}{l}\text { Resolving } \\
\text { interethnic } \\
\text { conflicts }\end{array}$} & \multirow{7}{*}{$\begin{array}{lr}\text { Establish } & \text { mutual } \\
\text { understanding } & \text { on } \\
\text { nonverbal level. } & \text { Form } \\
\text { empathic skills } & \text { and } \\
\text { ability to listen } & \end{array}$} & Exercise: Zoo \\
\hline & & & $\begin{array}{l}\text { Game-situation: Communication with } \\
\text { ethnic groups }\end{array}$ \\
\hline & & & $\begin{array}{l}\text { Exercise on methods for determining the } \\
\text { ability to listen }\end{array}$ \\
\hline & & & Exercise: Free communication \\
\hline & & & $\begin{array}{l}\text { Group discussion: Strategies for resolving } \\
\text { interethnic conflicts in the MEEPS }\end{array}$ \\
\hline & & & Game: Wolves and lambs \\
\hline & & & Reflection \\
\hline \multirow[t]{7}{*}{10} & & \multirow{7}{*}{$\begin{array}{l}\text { Understand main causes } \\
\text { of conflicts in the } \\
\text { MEEPS. Practice skills } \\
\text { to resolve interethnic } \\
\text { conflicts }\end{array}$} & Exercise: Circle with support \\
\hline & & & $\begin{array}{l}\text { Game: Social advertising of IT in the } \\
\text { MEEPS }\end{array}$ \\
\hline & & & Discussion: Frankly speaking \\
\hline & & & Exercise: I understand you \\
\hline & & & $\begin{array}{l}\text { Brainstorming: Causes of interethnic } \\
\text { conflicts in the MEEPS }\end{array}$ \\
\hline & & & $\begin{array}{l}\text { Reflection: Discussion on expectations } \\
\text { and hopes realization }\end{array}$ \\
\hline & & & Exercise: We, today \\
\hline
\end{tabular}

Project method. It contributed to the internal motivation improvement, stimulated scientific-practical activities and independent work of MedPT. It developed research and 
cognitive skills (analysis, observation, hypothesizing, generalization, and results presentation), the ability to take responsibility, actively participate in joint decision-making, resolve conflicts, and make informed choices. Project topics (Ethnic stereotypes; International marriage: pros and cons; Problems of interethnic communication; etc.) touched upon the universal values, as well as opposition "we - they", developing respect for ethnic groups. Projects were evaluated by relevance, structure, content, use of tables, etc.

Educational discussion. This method developed positive ethnic identity as the basis of respect for ethnic groups, logical and critical thinking, and communication skills. It was implemented by techniques "Discussion in a low voice" (first problem was discussed in microgroups, followed by a joint open discussion where leader reported the micro-group opinion, finalized with all-group discussion) and "Relay" (anyone who finished the speech gave the floor to whoever considered important).

Heuristic conversation. Through a series of skilful questions, an educator encouraged MEdPT to formulate new conclusions based on theoretical knowledge, life experience, and logical reasoning in the context of establishing tolerant relations with ethnic groups. Students explained differences in understanding the concepts of "family", "generation", "ethnicity", "nation", "nationality", and "people". MEdPT formulated the definition of "IT" and commented on possible reasons for the aggravation of interethnic relations.

Creative task. It included composing Haiku poems, work by "Who? What? Where? When? and Why?" method. Students in micro-groups prepared presentation on a particular culture, its features (language, history, traditions, folk crafts, folklore, religion etc.).

Cognitive games. They allowed the practical study of ethno-cultural traditions. For example, educators organized games: (i) "Invited dinner". Each student chose a particular ethnic group, introduced classmates to the peculiarities of its traditional cuisine. To do this, students cooked and treated one national dish, shared recipes and rules for cooking. An educator assessed the acquired knowledge on specifics of particular cuisine; (ii) "Who knows more?" Students in subgroups provided words-associations with a particular ethnic group without negative stereotypes (e.g. Belarusian culture - "barabola", "Alyosha”, "bison”; Uzbek - "satin robe", "tea", "pilaf"; Romanian - "mamaliga", "chorba", "vampires"). The group-winner provided the largest number of exact associations.

Role-playing. It developed in MEdPT practical skills to find the optimal solution and choose ways to demonstrate IT in the MEEPS. To form experience of constructive intercultural dialogue we organized games "Poland and Ukraine: dialogue of cultures" and "Ukraine and 
Hungary: features of national character".

Positive example. Because of perception of an individual's specific action, students acquired a subjective image of this action and a desire to do the same. A connection was formed between an example to follow and next steps - a synthesis of imitative and independent actions. We used "Map of IT" technique - students monitored media reports on IT issues and systematically marked on the map places, where events related to in / tolerant behavior took place. The "map" was discussed once a month.

Field practice required special attention, significantly influencing the formation of all IT indicators in the EG. It focused on expanding the ability to ensure compliance with social norms and rules of behavior in a multicultural society as well as positive interaction with ethnic groups. MEdPT performed self-analysis and self-assessment of professional activity in the MEEPS, concentrating on critical analysis of activity and specific social situation, informed decisions. In the reflective diary EG noted that they conducted with schoolchildren quiz (Discover the traditions of friendly peoples; Lesson of tolerance), drawing contest (Beauty of my country), educational hour (The country I live in), entertainment program (Slovak, Hungarian, Romanian, etc. folk games come to visit us), sports holiday (Entertainments of peoples of the world), and conversations (What is IT?; Treasures of humor from around the world).

Pedagogical experiment conducting was preceded by selecting:

- CG - 101 MedPT from Bohdan Khmelnytsky Cherkasy National University; Ivan Franko Zhytomyr State University, Kherson State University, Oleksandr Makarenko Sumy State Pedagogical University;

- EG - 98 MedPT from Bogdan Khmelnytsky Melitopol State Pedagogical University, Mukachevo State University, Yuriy Fedkovych Chernivtsi National University.

\section{Diagnostics of the levels of IT formed in MEdPT}

To diagnose the levels of IT formed by motivational-value component we used:

(i) "Methods of personal differential reflection" after Soldatova et al. (2008) to specify the stability of interest in studying the ethnic group culture, in particular, self-esteem and volitional qualities, evidence of extro / introversion in assessment and perception. MEdPT assessed display of 21 human qualities with points from " 3 - strongly displayed" to " 0 - it is difficult to say". Each quality corresponded to a particular scale - evaluation, strength, and activity. Positive qualities were marked “+”, negative - "-”. Maximum values ranged from +21 
to -21 . Interpretation of results: $21-17$ points - high level on a particular scale; $16-12-$ sufficient level; $11-7$ - average level; less than 6 - low level.

(ii) Questionnaire "Motivation in the learning activity of university students" after Ilyina (Darvish 2003). Statements corresponded to a particular scale - motivation to acquire knowledge, to master an occupation, and to get a diploma. MEdPT marked " + " if agreed and “-” if disagreed with the statement. Interpretation of results: $10-9$ points - high level on a particular scale; $8-6$ - sufficient level; 5-3-average level; 2-0-low level.

(iii) Rokeach value survey (Darvish 2003) to determine how MEdPT assessed instrumental value of "tolerance and tolerant attitude to the views and opinions of others".

(iv) "Cultural and value orientations test" after Pochebut (2012) to analyze how MEdPT understood lifestyle, values, behavior norms of ethnic groups based on three-culture types idea - traditional, modern, and dynamically developing.

To diagnose the levels of IT formed by cognitive component we used:

(i) "Assessment of individuals' sociability level” after Sulimova (1996). In particular, we assessed conflictedness and readiness for a contact. MEdPT chose one option from the listed answers to questions. Interpretation of results: $20+$ points - high level of conflictedness; it is difficult to establish positive relationships; 20-13 - sufficient level of conflictedness; inclination to conflict provoking; $12-6$ - average level of conflictedness; ready to establish a friendly relationship, open to compromise; 5-0 - low level of conflictedness; easily finds common ground and establishes a contact.

(ii) Author questionnaire to study the level of multicultural competence formed presented in the Table 6.

Table 6. Author questionnaire to study the level of multicultural competence formed

\begin{tabular}{|c|c|c|c|c|c|}
\hline № & Statement & yes & $\begin{array}{c}\text { rather yes } \\
\text { than no }\end{array}$ & $\begin{array}{c}\text { difficult to } \\
\text { answer }\end{array}$ & no \\
\hline 1 & $\begin{array}{l}\text { Active implementation of multicultural ideas } \\
\text { contributes to the formation of willingness to } \\
\text { cooperate in the multiethnic environment. }\end{array}$ & & & & \\
\hline 2 & $\begin{array}{l}\text { Modern pedagogical realities require taking into } \\
\text { account of ethno cultural factor and the provision } \\
\text { of conditions for learning the ethnic cultures and } \\
\text { fostering of tolerant relations. }\end{array}$ & & & & \\
\hline 3 & $\begin{array}{l}\text { Multicultural education expands the horizons of } \\
\text { educational activities, and cultivates tolerance as } \\
\text { a moral ideal and norm of behavior. }\end{array}$ & & & & \\
\hline 4 & $\begin{array}{l}\text { Professionally significant qualities of } \\
\text { multiculturalist teacher include: ability to adapt } \\
\text { to changes in pedagogical interaction; sociability; }\end{array}$ & & & & \\
\hline
\end{tabular}




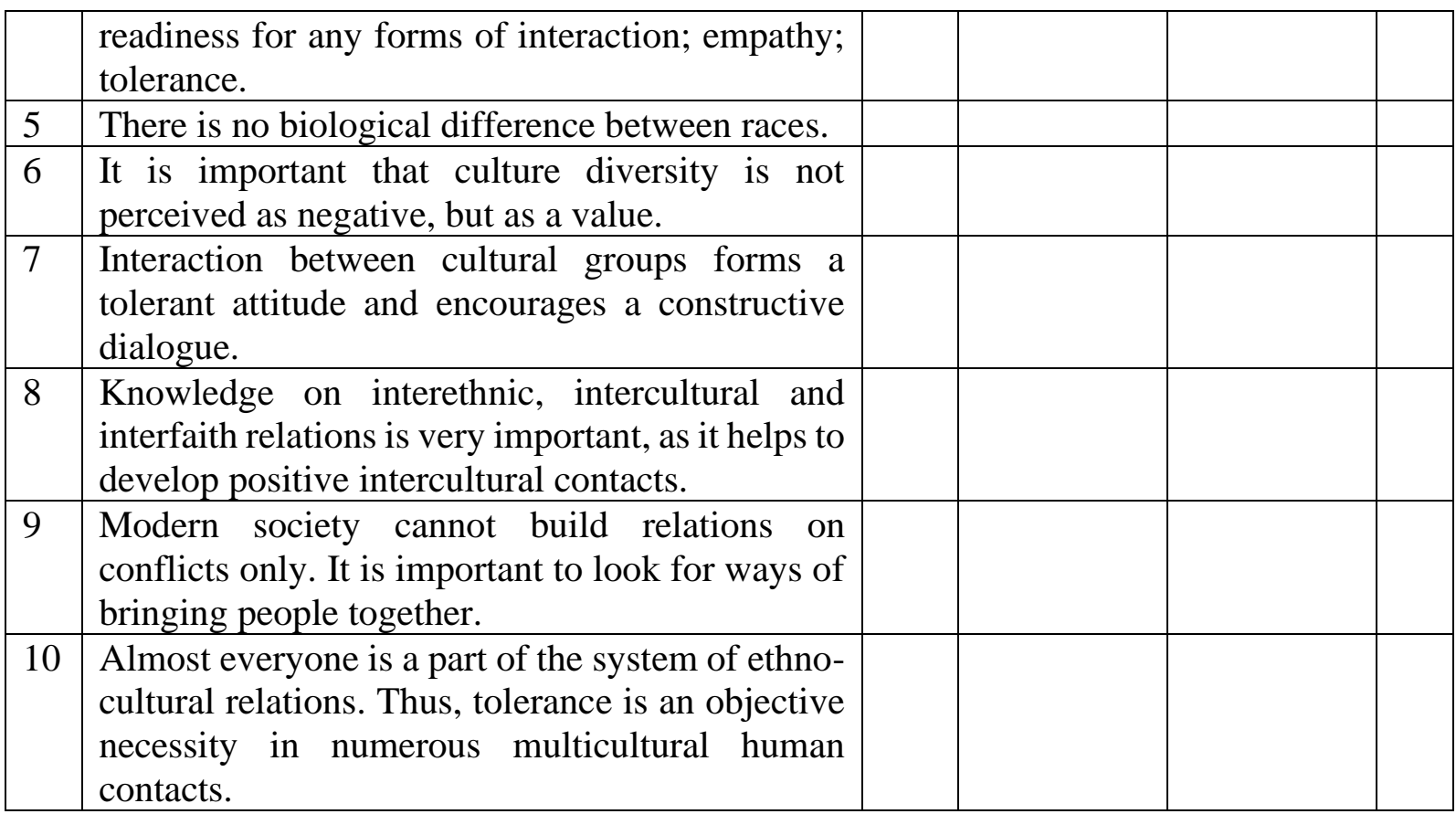

To diagnose the levels of IT formed by activity-behavioral component we used:

(i) Snyder (1974) method of "Assessment of communicative control" in communication with schoolchildren, their parents, colleagues in the MEEPS. MEdPT marked true/ false statements. Interpretation of results: $10-9$ points - high level of communicative control; $8-6$ - sufficient level; 5-3-average level; 2 - 0 - low level.

(ii) "Diagnosing the types of ethnic identity" after Soldatova et al. (2008) to analyze ethnic self-consciousness formed (by types of ethnic identity: ethno-nihilism, ethnic indifference, positive ethnic identity, ethno-egoism, ethno-isolationism, and ethno-fanaticism) and its transformation in conditions of interethnic tension. Statements on issues of national relations and culture were provided. MEdPT compared their opinion and scored points from "1 - disagree" to "4 - agree" for each ethnic identity type.

(iii) Bogardus' social distance scale (1933) to determine the indicator of ethnic stereotypes, social distance, and attitude towards ethnic groups.

To diagnose the levels of IT formed by reflexive-creative component we used:

(i) Karpov's (2003) “Assessment of individual reflection level”: situational (behavior control in real situations), retrospective (behavior control in past situations), and perspective (future plans analysis). Answers to direct statements scored points from "1 - absolutely disagree" to "7 - absolutely agree". A reverse point scale was assigned to reverse statements. Interpretation of results: $10-9$ points - high level of reflection developed; $8-6-$ sufficient level; 5 - 3 - average level; 2 - 0 - low level. 
(ii) Questionnaire "Index of tolerance" after Soldatova et al. (2008) to reveal in the context of in / tolerance the attitude towards social and ethnic groups, readiness for constructive conflict-solving cooperation, and respect for opponents' opinion. Answers to direct statements scored points from " 1 - absolutely disagree" to " 6 - absolutely agree"; a reverse point scale was assigned to reverse statements. Interpretation of results: $115+$ points - high level of tolerance; 112-90 - sufficient level; 89-51 - average level; 50-22 - low level.

(iii) Questionnaire "The level of empathy” after Yusupov (1995). Answers to 36 statements scored points from " 0 - absolutely disagree" to " 5 - absolutely agree". Interpretation of results: $82-90$ points - high level of empathy developed; $81-63$ - sufficient level; $62-37$ - average level; 36 - 5- low level.

Having applied diagnostic methods we transferred student's level of IT formed by each criterion into a four-point scale: low level - 1 point; average level - 2 points; sufficient level 3 points; high level -4 points.

The integrated indicator of IT level formed of $i$-student $\left(H_{i}\right)$ was calculated by the

formula: $H_{i}=\frac{M V_{i}+C_{i}+A B_{i}+R C_{i}}{4}$

(1), where $M V_{i}, C_{i}, A B_{i}, R C_{i}$ - the normalized values of motivational-value, cognitive, activity-behavioral, and reflexive-creative criteria.

$H_{i}$ was evaluated by the scale: 0-1 points corresponded to low level of IT formed; 1.1-2 - average level; 2.1-3 - sufficient level; 3.1-4 - high level. Table 7 demonstrates the results.

Table 7. The level of IT formed in MEdPT (in \%)

\begin{tabular}{lcccccccc}
\hline & \multicolumn{1}{c}{ Component } & \multicolumn{9}{c}{ Low } & \multicolumn{9}{c}{ Average } & \multicolumn{2}{c}{ Sufficient } & \multicolumn{2}{c}{ High } \\
& CG & EG & CG & EG & CG & EG & CG & EG \\
\hline Before the pedagogical experiment & & & & & & \\
\hline Motivational-value & 21.78 & 22.45 & 41.58 & 41.84 & 24.75 & 24.49 & 11.88 & 11.22 \\
Cognitive & 23.76 & 24.49 & 40.59 & 42.86 & 25.74 & 23.47 & 9.90 & 9.18 \\
Activity-behavioral & 25.74 & 26.53 & 34.65 & 34.69 & 25.74 & 25.51 & 13.86 & 13.27 \\
Reflexive-creative & 21.78 & 22.45 & 38.62 & 38.78 & 28.71 & 28.57 & 10.89 & 10.20 \\
General results & 23.26 & 23.98 & 38.86 & 39.54 & 26.23 & 25.51 & 11.63 & 10.96 \\
\hline After the pedagogical experiment & & & & & & & \\
\hline Motivational-value & 14.85 & 2.04 & 36.64 & 21.43 & 30.69 & 38.77 & 17.82 & 37.76 \\
Cognitive & 15.85 & 2.04 & 34.65 & 20.41 & 32.67 & 42.86 & 16.83 & 34.69 \\
Activity-behavioral & 15.84 & 3.06 & 29.7 & 28.57 & 34.65 & 36.74 & 19.81 & 31.63 \\
Reflexive-creative & 13.86 & 1.02 & 32.67 & 23.47 & 35.65 & 41.84 & 17.82 & 33.67 \\
General results & 15.11 & 2.04 & 33.41 & 23.47 & 33.41 & 40.05 & 18.07 & 34.44 \\
\hline
\end{tabular}


Diagnostics results at the pedagogical experiment beginning confirmed the need for targeted activities aimed to improve the level of IT formed in MEdPT to perform professional duties in the MEEPS. The majority of students had an average level of awareness of IT importance in the MEEPS and low level of knowledge on interethnic communication, multicultural competence and ethnic identity. They demonstrated unstable interest in studying of ethnic-cultural characteristics of ethnic groups participating in the MEEPS. Respondents lacked self-control, reflection, and demonstrated an egocentric life position, characterized by inability to care for MEEPS participants.

At the end of the pedagogical experiment, the level of IT formed in the EG significantly improved by all indicators. The intolerance displays decreased and the horizons to perform professional duties in the MEEPS significantly expanded. MEdPT began actively cooperate with ethnic groups, learned to establish a positive microclimate in the MEEPS. We observed the improvement of motivational-value sphere and a steady interest in studying the culture of ethnic groups. As a significant positive, students noted the in-depth knowledge on IT, acquired range of practical skills and abilities to work in the MEEPS. MEdPT improved personal qualities of sociability, friendliness, empathy, and the ability to reflect. During the field practice in the MEEPS the severity of interpersonal conflicts and disputes between schoolchildren, their parents, and colleagues decreased. Besides, EG students demonstrated adequate self-esteem and attentive attitude to the representatives of ethnic groups. Negative ethnic stereotypes were broken. Minimal social distance was observed, as well as a positive ethnic identity, a desire to cooperate with ethnic groups in the MEEPS.

\section{Discussion}

The 21st century globalization has caused the development of educational programs aimed to develop teachers who are competent to teach culturally diverse and tolerant students (Cochran-Smith, 2005; Darling-Hammond, 2006; Holland, 2013). "There is growing interest in global citizenship education as a framing paradigm that encapsulates how education can develop the knowledge, skills, values and attitudes learners need to secure more just, peaceful, tolerant and inclusive societies" (UNESCO, 2014, p.45).

More and more countries introduce the ideas of IT into the education system, state and public life, considering them as a means of forming and guaranteeing the society harmony. In developing requirements for teacher education programs, accreditation agencies emphasize the ensuring that these programs provide multicultural opportunities content for their students 
(NCATE-CAEP, 2008; Stephens et al, 2004). In its resolution Ukraine's Cabinet of Ministers (2018) clearly indicates, that the curriculum on training of MEdPT in terms of learning outcomes is to develop competency to: respect the diversity and multiculturalism; carry out professional activity on the principles of tolerance and non-judgmental attitude; resolve conflict situations and provide support in new, problematic and crisis situations; perform educational activities in the MEEPS.

In the process of professional training of future primary school teachers, it is important to provide appropriate conditions that promote students' knowledge and values on ethnic groups to form respect for culture, language, customs and beliefs. The specificity of modern processes of social-cultural development, the need to provide conditions for the development of constructive cross-cultural communication, equal dialogue, tolerance, empathy, universal values and ethics puts forward new priorities in the educational process of higher educational institutions. The search for and implementation of technologies aimed at the productive implementation of universal values in the global society, the transformation of human culture to more mobile, open, tolerant, moral and socially active, become increasingly important. Modern individual is placed on the "border" of cultures, interaction with which requires dialogue, respect for the cultural identity of others. Moreover, this is not only about ethnic groups, nations, religions, but also about their representatives. Thus, the modern model of social-cultural education should be human-centered and culture-oriented, be culturological.

Based on scientific analysis of works of Bakholskaya et al. (2019), Kizi (2020), we understand IT of primary school teachers as personal-professional qualities formed on the basis of humanistic worldview, allowing to perform professional duties effectively in the MEEPS, which foresee respect and understanding of educational environment participants, tolerant attitude towards them on the basis of openness in communication, affirmation of freedom of conscience and beliefs.

Intercultural student teaching is one way to transform propositional knowledge of diversity into practice as a means to develop multiculturalist teacher (Cushner, 2007; Sahin, 2008). We share the position of Dmitrieva et al. (2020), Tsvietkova et al (2019) that important personal-professional qualities of primary school teachers are: professionalism, responsibility, critical thinking, skills of interpersonal and team work, ability to make decisions and level up knowledge, demonstration of culture, ethics and communication skills, etc. In the context of our study, we add IT, toleration, the ability to prevent and resolve conflicts in the MEEPS, and high level of culture of interethnic communication. Matviienko (2019) points out openness to 
other cultures as the leading tendency in the development of professional training of future primary school teachers of the third millennium, detailing, that it involves personal-cultural development of an individual through involvement in cross-cultural activities, forming openness to other cultures, values, and views.

That is why the educational-cultural process in higher educational institutions requires providing and creating conditions for cross-cultural activities and taking into account of cultural environment in the process of inculturation of young people. The formation of IT of primary school teachers-to-be begins at faculties of primary education, responsible for enriching MEdPT with thorough knowledge on norms, principles and values of interethnic relations. They are to develop tolerance, positive moral feelings, sustainable behavior, and communication skills. In the context of our study, we believe that the training of primary school teachers is to be characterized by acquiring of didactic, subject and psychological-pedagogical knowledge and skills aimed to stimulate conditions for the development of cognitive interests and spiritual needs, intensifying educational-cognitive activity in a favorable multiethnic environment.

\section{Conclusions}

To improve the level of IT formed in MEdPT we developed and introduced methodical support for the effective organization of extra / curriculum, independent work and pedagogical practice. The developed learning procedure, implemented in the EG, gave positive results in the formation of IT by motivational-value, cognitive, activity-behavioral, and reflexive-creative components. In the professional context, EG minimized negative ethnic stereotypes and reduced intolerance. EG significantly expanded the horizons of professional activity in the MEEPS, developed positive ethnic identity and mastered communication skills. EG expanded multicultural competence and improved the level of sociability, reflexivity, and empathy. CG were unable to achieve independently significant positive results in the improvement of IT level. At the beginning of the pedagogical experiment, the values of active life and interesting work dominated (terminal values). At the end of it, in the CG they remained unchanged, while in the EG the values of cognition and development became decisive. The structure of dominant instrumental values remained unchanged in the CG. At the same time, in the EG, indicators of values of "tolerance", "tolerant attitude to the views and opinions of others", "the ability to forgive mistakes" improved. 


\section{References}

BAKHOLSKAYA, Natalia; NAZAROVA, Olga; VELIKANOVA, Svetlana; ZHAROVA, Ksenia; IGOSHINA Natalya; CHERNYKH, Oksana. Inter-ethnic tolerance and its development in pedagogical students of higher educational institutions. Amazonia Investiga, v.8, no.18, p.359-365, 2019.

BARTOSH, Olena. Intercultural competence as a part of professional qualities | Tarpkultūrinè kompetencija kaip profesinès kvalifikacijos dalis. Logos, no.104, p.148-155, 2020. doi: $10.24101 / \log 0$. 2020.59

BOGARDUS, Emory. A social distance scale. Sociology \& Social Research, no.17, p.265-271. 1933.

CABINET OF MINISTERS OF UKRAINE, Kyiv. Pro zatverdzhennya Derzhavnoho standartu pochatkovoyi osvity [On approval of the State primary education standard]. No 87 dated by February 21, 2018.

COCHRAN-SMITH, Marulyn. The new teacher education: for better or worse. Educational Researcher, v.34. no.7, p.3-17, 2005. doi: 10.3102/0013189X034007003

CUSHNER, Kenneth; BRENNAN, Sharon. (2007). The value of learning to teach in another culture. In: CUSHNER, Kenneth; BRENNAN, Sharon (Eds.). Intercultural student teaching: A bridge to global competence. Lanham: Rowman and Littlefield, 2007. p.1-12. DARLING-HAMMOND, Linda. Constructing 21st-century teacher education. Journal of Teacher Education, v.57, no.3, p.300-314, 2006. doi: 10.1177/0022487105285962 DARVISH, Olesya. Vozrastnaya psikhologiya [Age psychology]. Moscow: Vlados-Press, 2003.

DMITRIEVA, Stepanida; EVDOKAROVA, Tuara; STEPANOVA, Liubov; ABRAMOVA, Natalia; OKONESHNIKOVA, Nadezda. Development of ethnocultural competence in future primary school teachers. Gênero \& direito, v.9, no.2, 360-379, 2020. DOVHOPOLOVA, Yana. Formuvannya tolerantnykh vidnosyn studentiv u polikulkurnomu seredovyshchi vyshchoho navchalnoho zakladu [Formation of students' tolerant relations in the multicultural environment of universities]. Dissertation (Candidate of Pedagogical Sciences). V. Karazin Kharkiv National University, Kharkiv, Ukraine, 2007. FEDORCHUK, Viktor. Sotsialno-psykholohichnyy treninh "Rozvytok komunikatyvnoyi kompetentnosti vykladacha" [Social-psychological training "Development of teacher communicative competence"]. Kamianets-Podilskyi: Abetka, 2003.

GRYVA, Olha. Protsedury otsinky efektyvnosti shlyakhiv formuvannya tolerantnosti u molodi v polikulturnomu seredovyshchi [Estimation procedures on efficiency of ways to form youth tolerance in a multicultural environment]. Herald of Taras Shevchenko University of Kyiv. Series: Philosophy. Politology, no87, p.25-27, 2007.

HOLLAND, Christine. Classroom Intercultural Competence in Teacher Education Students, Interns, and Alumni. Dissertation (Doctor of Education). University of North Florida, Jacksonville, USA, 2013.

KAPIDINOVA, Susanna. Tolerantnist yak chynnyk rozvytku kultury mizhetnichnykh vidnosyn studentiv [Tolerance as a factor of development of culture of student interethnic relations]. Dissertation (Candidate of Psychological Sciences). Institute of Social and Political Psychology of the National Academy of Pedagogical Sciences of Ukraine. Kyiv, Ukraine, 2015.

KARPOV, Anatoly. (2003). Reflecsivnost kak psihicheskoe svoystvo i metodika eyo diagnostiki [Reflectiveness as a mental quality and the method to diagnose it].

Psikhologicheskii Zhurnal, v.5, no.24, p45-57, 2003.

KHOMA, Olha. (2013). Metodychna pidhotovka maybutnikh uchyteliv pochatkovoyi shkoly $\mathrm{v}$ umovakh universytetu [Methodical training of future primary school teachers in universities]. In: YEVTUKH, Mykola; Hertsyuk, Dmytro; Shmydt, Kostyantyn (Eds.). 
Pedahohichna osvita i nauka v umovakh klasychnoho universytetu: tradytsiyi, problemy, perspektyvy. Tom 1: Pidhotovka pedahohichnykh kadriv u vyshchiy shkoli: vyklyky, problemy, dynamika zmin [Pedagogical education and science in classical university conditions: traditions, problems, prospects. Vol 1: Training of high school teachers: challenges, problems, dynamics of change]. Lviv: I. Franko Lviv National University, 2013. p.288-295.

KIZI, Samadova Sarvinoz Samad. Tolerance of future teachers in the further development of interethnic relations in education. European Journal of Research and Reflection in Educational Sciences, v.8, no.2, p.134-137, 2020.

KONDRATIEVA, Olena. Formuvannya polikulturnoyi kompetentnosti maybutnikh uchyteliv pochatkovoyi shkoly na zasadakh linhvokrayinoznavchoho pidkhodu [Formation of multicultural competence of future primary school teachers on the basis of linguistic and local lore approach]. Dissertation (Candidate of Pedagogical Sciences). National Pedagogical M. Dragomanov University, Kyiv, Ukraine, 2016.

MATVIIENKO, Olena. Profesiyna pidhotovka maybutnoho vchytelya pochatkovoyi shkoly u formati suchasnykh modernizatsiynykh protsesiv $\mathrm{v}$ osviti [Future primary school teacher professional training in the format of contemporary modernization in education. In: TSVETKOVA, Hanna (Ed.). Professional development of the teacher in the light of European integration processes. Hameln: InterGING, 2019. p.28-46.

NATIONAL COUNCIL FOR ACCREDITATION OF TEACHER EDUCATION. COUNCIL FOR THE ACCREDITATION OF EDUCATOR PREPARATION. Professional standards for the accreditation of teacher preparation institutions. Washington, DC: National Council for Accreditation of Teacher Education. 2008. Available at: http://www.ncate.org/Portals/0/documents/Standards/NCATE\%20Standards\%202008.pdf. Accessed on: 27 Aug. 2018.

PASHCHENKO, Dmytro. Formuvannya hotovnosti maybutnikh uchyteliv pochatkovykh klasiv do humanitarnoho vykhovannya uchniv [Formation of readiness of future primary school teachers for humanitarian education of schoolchildren]. Dissertation (Doctor of Pedagogical Sciences). National Pedagogical M. Dragomanov University, Kyiv, Ukraine, 2006.

POCHEBUT, Ludmila. Kross-kulturnaya i etnicheskaya psikhologiya [Cross-cultural and ethnic psychology]. St. Petersburg: Piter Publ., 2012.

SAHIN, Mehmet. Cross-cultural experience in intern education. Teaching and Teacher Education, v.24, no.7, p.1777-1790, 2008. doi: 10.1016/j.tate.2008.02.006

SLYUSARENKO, Olena; KADANER, Oksana. Pidhotovka maybutnikh uchyteliv pochatkovykh klasiv do vykhovannya mizhetnichnoyi tolerantnosti molodshykh shkolyariv [Training of future primary school teachers to develop interethnic tolerance of junior pupils]. Young Scientist, v.2, no.42, p.540-544, 2017.

SMULSON, Maryna. Trening "Konflikty i ikh razresheniye" [Training "Conflicts and their resolution"]. Kyiv: Nora-print, 2004.

SNYDER, Mark. Self-monitoring of expressive behavior. Journal of Personality and Social Psychology, v.30, no.4, p.526-537, 1974.

SOLDATOVA, Galina; SHAIGEROVA, Ludmila; PROKOFIEVA, Tatyana;

KRAVTSOVA, Olga. Psikhodiagnostika tolerantnosti lichnosti [Psychodiagnostics of personality tolerance]. Moscow: Smysl, 2008.

STEPHENS, Paul; TØNNESSEN, Finn Egil; KYRIACOU, Chris. Teacher training and teacher education in England and Norway: a comparative study of policy goals. Comparative Education, v.40, no.1, p.109-130, 2004. doi: 10.1080/0305006042000184908 


\section{SULIMOVA, Ttatyana. Sotsialnaya rabota i konstruktivnoye razresheniye konfliktov}

[Social work and constructive conflict resolution]. Moscow: Institute of Practical Psychology, 1996.

TIHOMIROVA, Olga. (2011). Soderzhanie professionalnoj kompetentnosti pedagoga v predshkolnom obrazovanii [Content of professional competency of the teacher in preschool education]. Jaroslavl pedagogical Bulletin. Series: Psychological-pedagogical sciences, 2, 193-197.

TSVIETKOVA; Hanna; PANASENKO, Ellina; VOITYUK; Irina. Concept of professional training of Masters of Preschool Education. In: TSVETKOVA, Hanna (Ed.). Professional development of the teacher in the light of European integration processes Hameln: InterGING, 2019. p.5-27.

TYSHYK, Iryna. Mahisterskyy etap pidhotovky maybutnoho vykladacha istoriyi do formuvannya mizhetnichnoyi tolerantnosti [Master degree of history teachers training for interethnic tolerance formation]. Scientific Bulletin of the South Ukrainian State Pedagogical University named after K.D. Ushinskyi, no.5-6, p.216-222, 2013. UNESCO education strategy 2014-2021. Director-General, 2009-2017 (Bokova, I.G. writer of foreword). UNESCO. 2014.

YUSUPOV, Ildar. Psikhologiya empatii: teoreticheskiye i prikladnyye aspekty [Psychology of empathy: theoretical and applied aspects]. Dissertation (Doctor of Psychological Sciences). St. Petersburg State University, St. Petersburg, Russia, 1995.

\section{ABOUT THE AUTHORS}

Olena Bartosh. Candidate of Pedagogical Sciences, Associate Professor, Department of Sociology and Social Work, State University "Uzhhorod National University", Uzhhorod, Ukraine. Author of more than 170 scientific publications on theory and methods of professional education. Scientific supervisor of 3 candidate dissertations ( $\mathrm{PhD}$ in Pedagogy). Member of the editorial board of Scientific Bulletin of Uzhhorod University. Series: "Pedagogy Social work" (Ukraine): $\quad$ http://visnyk-ped.uzhnu.edu.ua/about. $\quad$ Google Scholar: https://scholar.google.com/citations?hl=uk\&authuser=2\&user=Y0rdicoAAAAJ;

ResearcherID: http://www.researcherid.com/rid/F-5853-2019; Scopus Author: https://www.scopus.com/authid/detail.uri?authorId=57211458378

Tetiana Atroshchenko. Doctor of Pedagogical Sciences, Assistant Professor, Department of Pedagogy of Preschool and Primary Education, Mukachevo State University, Mukachevo, Ukraine. Author of more than 150 scientific publications on theory and methods of professional education.

Scholar: https://scholar.google.com.ua/citations?hl=uk\&user=Cln7d7AAAAAJ\&view_op=list_works \&sortby=pubdate

Iryna Kozubovska. Doctor of Pedagogical Sciences, Professor, Department of General Pedagogy and Pedagogy of Higher School, State University "Uzhhorod National University", Uzhhorod, Ukraine. Author of more than 500 scientific publications on theory and methods of professional education. Google

Scholar:

https://scholar.google.com/citations?hl=uk\&authuser=2\&user=ypHVt_gAAAAJ

\section{Como citar este artigo (ABNT):}

BARTOSH, Olena; ATROSHCHENKO, Tetiana; KOZUBOVSKA, Iryna. Enhancing interethnic tolerance in masters of education in Ukrainian multiethnic primary school. Revista Práxis Educacional, Vitória da Conquista, v. 18, n. 49, 2022. https://doi.org/10.22481/praxisedu.v18i49.9262 